\title{
REPUTATION EVALUATION OF THE FACTORS REGULATING THE DEVELOPMENT OF THE CONSUMER GOODS MARKET IN THE REGION
}

\author{
NAZARIY POPADYNETS, VIKTORIYA BONDARENKO, ROMA STARYK, OlHA CHAKII, OlHA \\ VOITENKO
}

\begin{abstract}
The article substantiates the essence of dysfunctions as a key phenomenon that leads to deformation or partial failure to perform functions by the subjects of the internal consumer market. The features of the influence of socio-economic factors investigated within the functioning efficiency of the regional food market. The evaluation of the influence for the food market factors in the region carried out by classifying the factors by the influence sphere and the regulation degree, assessing the influence of the food market factors on the main indicator models. These models contain indicators, despite the existing system of statistical observation in the region, studying the relationships between factors and indicators characterizing food market and identifying the results of dysfunctions. A block of socio-economic determinants of realizing the potential of the consumer (food) market in the region is proposed. Correlation analysis of factors affecting the food market and the volume of products sold (agriculture, food production, beverages) has been carried out. The authors built a system of correlation between the socio-economic factors of the food market and the export of agricultural products and the food industry in the region. A system of interrelation of socioeconomic factors and their influence on the wholesale turnover of food products in the region proposed, as well as a system of interrelation of socio-economic factors with the resulting "gross regional product". The nature of the emergence and the essence of dysfunctions in the regulation of the consumer market development are concretized. The consequences of state regulation dysfunctions for the development of the consumer goods internal market are determined and characterized. The main dysfunctional factors of influence on the regulators of the regional market development grouped in the aspect of competitive markets.
\end{abstract}

Keywords: consumer market, food products, socio-economic factors, dysfunctions, potential.

JEL Classification: L10, L11, L51, L81.

\section{INTRODUCTION}

A number of economic, socio-demographic, infrastructural, environmental and political factors influences the internal market of consumer (food) goods of the regions of Ukraine. The effect of these 
factors can be both positive and negative. In the context of food security, the main goal of the authorities is to provide citizens with an adequate level of consumer goods and food, that is, food security. In modern conditions of a rapidly changing global environment, a large number of factors affect the level of food security and, as a result, is both a consequence and the basis of changes in the foreign and internal policy of the state. Determining the influence of these factors is of great importance in the context of effective government regulation of the internal food market and can become a fundamental basis for programs and strategies for food security at the regional and macro levels.

\section{THEORETICAL BACKGROUND}

The relevance of the researching problem certified by a number of scientific publications in this area, in particular, a preliminary study carried out about the regulation of the internal consumer market at the level of Ukraine [1]. No less important are the authors' studies of the basic formation principles of regional markets for consumer goods [2] or the definition of the institutional model of the internal market for consumer goods [3], as well as the definition of marketing tools to influence the consumer market [4]. About the very essence of the consumer market, L. Lihonenko determined quite thoroughly. She insisted that the consumer market is one of the segments (subsystems) of the market, characterizing the totality of socio-economic relations between the producer and the consumer, which are formed in the process of buying and selling (renting) consumer goods and services for final (personal) consumption [5, p. 10]. T. Yakhno in her research revealed the essence of the consumer market somewhat more broadly, dividing it according to certain criteria, namely: 1) as a system of various relationships between its subjects, taking place to resolve issues of exchange of created goods (consumer goods and services); 2) as a link of public reproductive process; 3 ) as a set of consumers of the created social value [6]. M. Drahomyretska in the function of the consumer market also includes motivational and equivalent functions [7, p. 113]. He notes that the consumer market is not only the main component of the market economy, provides close interaction between sellers and buyers of consumer goods and services, but also a tool for ensuring the balanced development of the spheres of production, distribution, exchange and consumption of a social product. Nevertheless, A. Ivashchenko adds to these functions a conciliatory, evaluative and savings function [8]. O. Azarian considers the consumer market, as a system of economic relationships that realized through economic needs [9, p. 6].

H.V. Kaplenko provided a thorough interpretation of the essence of the consumer goods market with the definition of its functions in her research, who considers it as a specific institution that characterizes the totality of socio-economic relations that combine the production of consumer goods, their distribution, consumption, regulation and plays the leading role. role in the reproduction of labour, ensuring relationships both between the seller (manufacturer), intermediary and buyer (consumer), and between individual industries, regions of the country and other states [10].

Paying tribute to the refinement of scientists in this area, it is worth noting that it requires careful substantiation of dysfunctional phenomena that transform the market environment and put forward new requirements for the activities of market entities in modern conditions, in particular at the regional level.

\section{Research Objective, Methodology and Data}

The purpose of the article is to determine the main dysfunctional factors of influence on the regulation of the consumer goods market development in the region.

Within the framework of the research, we consider it expedient to classify factors into regulated and unregulated ones and form them according to spheres of influence for ease of use in public administration practice.

Because of the factor's systematization, a socio-economic group of determinants identified for realizing the internal food market potential (Tab. 1). 


\begin{tabular}{|c|c|c|}
\hline Factor name & $\begin{array}{l}\text { The influence mechanism on the potential } \\
\text { realization of the internal market of consumer goods }\end{array}$ & Factor type \\
\hline 1 & 2 & 3 \\
\hline $\begin{array}{l}\text { Sectorial structure of } \\
\text { the food market }\end{array}$ & $\begin{array}{l}\text { For decrees and orders has a direct impact on the } \\
\text { sectors of the food market. The Agrarian Fund } \\
\text { through public procurement forms an intervention } \\
\text { fund to meet the food needs of the population and } \\
\text { ensure food independence of Ukraine }\end{array}$ & $\begin{array}{l}\text { Regulatory: direct } \\
\text { impact }\end{array}$ \\
\hline Resident population & By changing migration and social policies & $\begin{array}{l}\text { Regulatory: indirect } \\
\text { influence }\end{array}$ \\
\hline Amount of wages & $\begin{array}{l}\text { Direct influence on the volume of the minimum wage, } \\
\text { which underlies the indexation of wages, and the } \\
\text { impact through charges on the wage fund consumer } \\
\text { goods market is increasing }\end{array}$ & $\begin{array}{l}\text { Regulatory: direct } \\
\text { impact }\end{array}$ \\
\hline Employment rate & $\begin{array}{l}\text { The larger the people employed number in the } \\
\text { country, the more the purchasing power of the } \\
\text { population grows, and accordingly, the level of } \\
\text { potential use of the internal market for consumer } \\
\text { goods increases }\end{array}$ & $\begin{array}{l}\text { Regulatory: indirect } \\
\text { influence }\end{array}$ \\
\hline Household income & $\begin{array}{l}\text { Due to the impact on the sources of the formation of } \\
\text { household income, primarily social payments from } \\
\text { the State budget and other }\end{array}$ & $\begin{array}{l}\text { Regulatory: indirect } \\
\text { influence }\end{array}$ \\
\hline $\begin{array}{c}\text { Household } \\
\text { expenditures }\end{array}$ & $\begin{array}{l}\text { Due to changes and regulation of the price of } \\
\text { foodstuffs }\end{array}$ & $\begin{array}{l}\text { Regulatory: indirect } \\
\text { influence }\end{array}$ \\
\hline $\begin{array}{l}\text { Purchasing power of } \\
\text { the population }\end{array}$ & $\begin{array}{l}\text { Through the mechanism of increasing the income } \\
\text { level of Ukrainian citizens, stimulating and increasing } \\
\text { the production of agricultural products and food } \\
\text { products, which will create conditions for saturating } \\
\text { the internal market and stabilizing prices for such } \\
\text { goods }\end{array}$ & $\begin{array}{l}\text { Regulatory: indirect } \\
\text { influence }\end{array}$ \\
\hline $\begin{array}{l}\text { Level of consumption } \\
\text { by households }\end{array}$ & $\begin{array}{l}\text { By setting prices for certain groups of goods, } \\
\text { providing material assistance }\end{array}$ & $\begin{array}{l}\text { Regulatory: direct } \\
\text { impact }\end{array}$ \\
\hline $\begin{array}{l}\text { Availability of credit } \\
\text { resources }\end{array}$ & $\begin{array}{l}\text { By providing preferential loans for business entities } \\
\text { in agriculture, the agricultural sector and the food } \\
\text { industry }\end{array}$ & $\begin{array}{l}\text { Regulatory: direct } \\
\text { impact }\end{array}$ \\
\hline Export volumes & $\begin{array}{l}\text { Establishment of an embargo on food products, which } \\
\text { are necessary to ensure the internal market }\end{array}$ & $\begin{array}{l}\text { Regulatory: direct } \\
\text { impact }\end{array}$ \\
\hline Import volumes & $\begin{array}{l}\text { Support protectionist policies to ensure the } \\
\text { development of internal food producers }\end{array}$ & $\begin{array}{l}\text { Regulatory: direct } \\
\text { impact }\end{array}$ \\
\hline $\begin{array}{l}\text { Infrastructure } \\
\text { support }\end{array}$ & $\begin{array}{l}\text { By creating effective means of promoting products } \\
\text { from producer to consumer in the country }\end{array}$ & $\begin{array}{l}\text { Regulatory: indirect } \\
\text { influence }\end{array}$ \\
\hline $\begin{array}{l}\text { Level of science and } \\
\text { technology } \\
\text { development }\end{array}$ & $\begin{array}{l}\text { Modern advances in science and technology have a } \\
\text { positive effect on productivity, innovation, } \\
\text { competitiveness, cost of food production }\end{array}$ & $\begin{array}{l}\text { Regulatory: indirect } \\
\text { influence }\end{array}$ \\
\hline $\begin{array}{l}\text { Amount of taxes and } \\
\text { fees }\end{array}$ & $\begin{array}{l}\text { Reducing the tax burden makes it possible to raise } \\
\text { additional funds for production }\end{array}$ & $\begin{array}{l}\text { Regulatory: direct } \\
\text { impact }\end{array}$ \\
\hline
\end{tabular}




\begin{tabular}{|c|c|c|}
\hline Factor name & $\begin{array}{c}\text { The influence mechanism on the potential } \\
\text { realization of the internal market of consumer goods }\end{array}$ & Factor type \\
\hline $\begin{array}{c}\text { Level of the crop } \\
\text { production sector } \\
\text { development }\end{array}$ & $\begin{array}{c}\text { By determining the size of cultivated areas, setting } \\
\text { quotas for imports and exports and ordering grain } \\
\text { crops for the internal market }\end{array}$ & $\begin{array}{c}\text { Regulatory: indirect } \\
\text { influence }\end{array}$ \\
\hline $\begin{array}{c}\text { Level of the livestock } \\
\text { sector development }\end{array}$ & $\begin{array}{c}\text { By determining quotas for imports of products by } \\
\text { domestic enterprises and ordering cereals for the } \\
\text { internal market }\end{array}$ & $\begin{array}{c}\text { Regulatory: indirect } \\
\text { influence }\end{array}$ \\
\hline $\begin{array}{c}\text { Investment climate } \\
\text { Creation of conditions for attracting foreign } \\
\text { investment and providing loans to enterprises aimed } \\
\text { at creating new, reconstruction, expansion and } \\
\text { modernization of existing fixed assets of enterprises }\end{array}$ & $\begin{array}{c}\text { Regulatory: indirect } \\
\text { influence }\end{array}$ \\
\hline $\begin{array}{c}\text { Availability of food } \\
\text { products on the } \\
\text { market }\end{array}$ & $\begin{array}{c}\text { By monitoring the situation in the wholesale and } \\
\text { retail markets of food products to fully provide } \\
\text { domestic consumers }\end{array}$ & $\begin{array}{c}\text { Regulatory: indirect } \\
\text { influence }\end{array}$ \\
\hline
\end{tabular}

Tab. 1. Block of socio-economic determinants for realizing the consumer (food) market potential in the region.

* Source: developed by the authors

It should be note that socio-economic factors characterize the ability of a state or region to realize the agro-industrial complex potential, aimed at self-sufficiency of the population with the internal food market due to high purchasing power and population employment.

This approach, in our opinion, provides an understanding of the set of tools / measures that can use by public authorities to neutralize the negative impact of each of the factors and transform the circumstance from a disincentive into a stimulator for realizing the domestic food market potential in the region.

With regard to socio-economic factors, it is worth focusing on such a factor as the purchasing power of the population, because the state, through the mechanism of increasing the level of citizens' incomes, stimulates an increase in agricultural production, the volume of food products and, as a result, the internal market of food products is saturated and prices decrease.

An important role in realizing the internal market potential let to the level of science and technology development, because modern advances in science and technology have a positive effect on productivity, innovation, competitiveness, and the cost of food production. The authorities in this direction should exercise an indirect influence by stimulating the introduction of innovative technologies, products through the prism of preferential taxation, depreciation and other measures.

In the context of the global environment instability and insufficient financial and credit resources, investments (domestic and foreign) are an important source, which is why the authorities must create stable and favourable conditions for attracting foreign investment and providing loans to enterprises aimed at creating new, reconstruction, expansion and modernization operating fixed assets of enterprises.

One of the analysis types is correlation-regression, which allows identifying the relationship between factors and showing the extent of this relationship. The dependence of one random variable on another random variable is regression, and the presence of a relationship between two random variables is correlation. It is two economic and mathematical methods that have been investigated which factors today influence the most (as stimulants or de-stimulants) on the realization of the internal consumer market potential, and it is possible to determine the consequences of the action of dysfunctions in the food market. Within the framework of this subdivision, their consequences considered the disruption of ties, conditioned by the laws of economics.

The first step in the implementation of this study will be to search for dependencies (tightness of the relationship) between certain indicators and the resulting indicators, which will reflect the degree of influence of the relevant factors and indicate the consequences of dysfunctions. The second is to test 
the hypothesis about the existence of a connection by comparing the calculated value of the pair correlation coefficient ( $\mathrm{R}$ calcul.) with the critical one ( $\mathrm{R}$ critic.) (Formula 1).

$$
\text { R calcul. } \geq \text { R critic. }
$$

If this inequality fulfilled, then with a degree of probability of $95 \%$, it can be argued that there is a close relationship between these factors. Considering the number of statistical observation periods $(\mathrm{n}=$ 10) for each type of factors interconnection and the resulting correlation coefficient, the critical correlation coefficient is 0.702 , therefore, all $\mathrm{R}$ calcul. will be taken into account, which is within this critical value.

The economic and mathematical research of the determinants influence on the internal food market has several limitations:

1) For modelling, only quantitative indicators were taken with the number of observation periods $10(\mathrm{n}=10)$, which is a sufficiently long and permissible period for economic mathematical modelling.

2) The investigated interconnections and the built economic and mathematical models are only a simplified description of the economic process, connections for the possibility of their management or regulation in the future. However, it should understand that a significant change in the studied connections, built models can be influenced by the people behaviour, their interests and individually made decisions of the authorities.

3) All models and relationships are built on past evidence, however, today's rapidly changing global environment does not $100 \%$ guarantee the effectiveness of models and relationships today and in the future.

To obtain the most accurate results, all the constructed economic and mathematical models and connections tested for adequacy and effectiveness.

Within the framework of this direction, the following are determined:

1. correlations between factors (in our case, between indicators that characterize regardless of the sphere and regulatory type);

2. relationships between the indicators of factors and the resulting indicators. As the resulting indicators "y", which exactly according to the method of statistical observation reflect the level of the food market development in the region are:

2.1 volume of products sold in agriculture and food industry $\left(\mathrm{y}_{1}\right)$;

2.2 export volumes of agricultural and food industry products (y2);

2.3 wholesale turnover of food products (y4);

2.4 volume of gross value added generated in agriculture (GVA agr.), food and beverage production (GVA f.b.) (however, there are no official data of the GVA in the food industry).

These indicators, taking into account the methodology of statistical observation in the regions of Ukraine, had better reflect the internal food market potential in the region.

3. determination of the consequences/results of dysfunctions of the internal food market. Due to distorted expected relationships, that is, those that violate the expected hypotheses according to existing economic laws and principles. Accordingly, it can be assumed that functional ties are broken in the food market and require corrective (regulatory) influence from the regional authorities.

\section{RESUlts AND DisCUSSION}

According to the analysed statistical data for the Lviv region, Tab. 2 presents the results of the existing relationships with the volume of products sold in the Lviv region (agriculture, food production, beverages) (y1).

From the data in Tab. 2, it can be seen that a number of socio-economic factors affect the volume of products sold in agriculture and the food industry (the resulting indicator of the food market). An inverse relationship was revealed between the share of non-food products sales produced in the country and $\mathrm{y} 1$ (correlation coefficients, respectively, -0.754 ), that is, it can be concluded that the sale of agricultural products is associated with the export of products to foreign markets. 
The results of dysfunctions, in our opinion, in the food market evidence by the inverse relationship between the number of resident population and the resulting population y1 (-0.958). An analysis of the factual database indicates the annual rate of decline in the resident population and the annual growth rate of agriculture and the food industry - respectively the expected dysfunctional relationship. However, it can be assumed that an increase in the resident population does not provide for an increase in the consumption of internal food products, it is also not logical with from the food security point of view of both the region and the country. A specific feature is a direct relationship between the number of resident population in the age group "0-15" (0.905), "over 60" and the volume of $\mathrm{y} 1$.

The expected and significant is the relationship of $\mathrm{y} 1 \mathrm{with}$ the volume of the minimum wage $(0.951)$, the percentage of deductions from wages (0.956) and the available income per person (0.989). That is, the more income (including wages), the more consumer spending in households, and, consequently, the greater the volume of agricultural and food products sold. That is, with an increase in purchasing power, the volume of production and sales of food products will increase, since demand stimulates a greater supply of food products.

\begin{tabular}{|c|c|}
\hline Indicators that reflect the influence of factors & $\left(\mathrm{y}_{1}\right)$ \\
\hline Wholesale turnover, UAH million, food products & 0.984 \\
\hline Share in wholesale turnover, $\%$, food products & 0.754 \\
\hline Share in wholesale turnover, $\%$, non-food products & -0.754 \\
\hline Number of resident population, thousand people & -0.958 \\
\hline Number of resident population by age groups (0-15 years), thousand people & 0.905 \\
\hline Number of resident population by age groups (16-59 years), thousand people & -0.993 \\
\hline Number of resident population by age groups (over 60), thousand people & 0.987 \\
\hline Volume of the minimum wage, UAH & 0.951 \\
\hline Percentage of deductions from wages & 0.956 \\
\hline The unemployed population, on average, thousand people & -0.805 \\
\hline Available income per person, $\mathrm{UAH}$ & 0.989 \\
\hline $\begin{array}{l}\text { The structure of total household food expenditures on average per month per household, } \\
\text { UAH }\end{array}$ & 0.986 \\
\hline Final consumer expenditures of households for foodstuffs, UAH million & 0.968 \\
\hline Average monthly expenses per household, UAH & 0.971 \\
\hline Consumption total expenditure on food and non-alcoholic beverages (\%) & -0.832 \\
\hline $\begin{array}{l}\text { Consumption of oil and other vegetable fats in households on average per month per person, } \\
\mathrm{kg}\end{array}$ & -0.951 \\
\hline Consumption of potatoes in households on average per month per person, $\mathrm{kg}$ & -0.828 \\
\hline $\begin{array}{l}\text { Consumption of bread and bread products in households on average per month per person, } \\
\mathrm{kg}\end{array}$ & -0.900 \\
\hline Volumes of the agricultural products exports, USD thousand & 0.832 \\
\hline Volumes of the food industry imports, USD thousand & 0.762 \\
\hline Volume of transported goods by types of transport, thousand tones & 0.798 \\
\hline Expenditures on innovations, UAH million & 0.828 \\
\hline Sown area of agricultural crops, thousand hectares & 0.824 \\
\hline Crop yield, c per 1 ha of harvested area & 0.907 \\
\hline Volume of production (gross yield) of agricultural crops, thousand centners & 0.761 \\
\hline Production of main types of livestock products, thousand tons & -0.979 \\
\hline $\begin{array}{l}\text { Average prices of agricultural products sold by enterprises (cereals and legumes), UAH per } \\
\text { ton }\end{array}$ & 0.952 \\
\hline Average prices of agricultural products sold by enterprises (sunflower), UAH per ton & 0.851 \\
\hline Average prices of agricultural products sold by enterprises (potatoes), UAH per ton & 0.861 \\
\hline
\end{tabular}




\begin{tabular}{|l|c|}
\hline \multicolumn{1}{|c|}{ Indicators that reflect the influence of factors } & $\left(\mathrm{y}_{1}\right)$ \\
\hline Average prices of agricultural products sold enterprises (vegetable crops), UAH per ton & $\mathbf{0 . 9 2 0}$ \\
\hline Average prices of agricultural products sold by enterprises (farm animals), UAH per ton & $\mathbf{0 . 9 9 0}$ \\
\hline Average prices of agricultural products sold by enterprises (milk), UAH per ton & $\mathbf{0 . 9 8 2}$ \\
\hline $\begin{array}{l}\text { Average prices of agricultural products sold by enterprises (eggs, per thousand), UAH per } \\
\text { ton }\end{array}$ & $\mathbf{0 . 9 3 3}$ \\
\hline Average prices of agricultural products sold by enterprises (all together), UAH per ton & $\mathbf{0 . 9 9 0}$ \\
\hline Foreign direct investment in agriculture, forestry and fisheries, USD thousand & $-\mathbf{0 . 7 8 3}$ \\
\hline Capital investments in agriculture, hunting and provision of related services, UAH thousand & $\mathbf{0 . 9 7 1}$ \\
\hline $\begin{array}{l}\text { Capital investments of industrial enterprises (production of food, beverages and tobacco } \\
\text { products), UAH thousand }\end{array}$ & $\mathbf{0 . 9 2 7}$ \\
\hline GRP of the region, UAH million & $\mathbf{0 . 9 9 5}$ \\
\hline
\end{tabular}

Tab. 2. Correlation analysis of factors affecting the food market and the volume of products sold (agriculture, food production, beverages) in the Lviv region ( $\left.y_{1}\right)$.

* Source: calculated by the authors

The larger the number of unemployed population in the Lviv region, the lower the volume of sold agricultural and food products (-0.805). The direct relationship between the final consumer spending of households on food and in $\mathrm{y}_{1}$ indicates the demand for internal food products, is positive from the regional food security point of view, but the consumption of oil and other vegetable fats may indicate the attractiveness of imported goods for consumers of this type of activity.

The evidence of dysfunction in the Lviv region is the feedback between $\mathrm{y}_{1}$ and the consumption of potatoes (-0.828) and bread, bread products (-0.900). Also dysfunctional is the direct impact of increasing imports of agricultural products on the sales of the same products. Thus, it showed a positive correlation coefficient between the corresponding indicators (0.762).

The direct impact of costs on innovation (0.828) and the resulting $\mathrm{y}_{1}$ is important, as it indicates the innovative activity of enterprises in the food sector and the positive impact of this factor on the increase in sales volumes.

Functional has direct correlation with the sown area (0.824), crop yield (0.907), and gross yield (0.761).

The increase in prices for products of the food market logically and functionally has a positive effect on the increase in sales volumes; however, from the standpoint of the consumer, this is a completely positive factor and indicates an increase in the cost of the consumer basket in dynamism and the absence of an alternative to food products.

Dysfunctional, in our opinion, is the inverse relationship between direct foreign investment and y1: this situation may indicate that foreign investments ineffectively invested in agricultural and food enterprises, but an increase in capital investment has a positive effect on the volumes of y1. In general, indicators the investment factor, indicate its significant impact on the level of food security, however, the presence of dysfunctional links indicates the need for government intervention and regulation of the investment climate in the region.

Functionally logical is the positive effect of labour productivity on the increase in sales in agriculture and food industry, and in turn, on the volume of gross domestic product, which showed the corresponding correlation coefficients (0.995).

Each region is interested in a positive foreign trade balance, according to it is important to understand what factors and through which regulators can influence this indicator. That is why the results of the correlation analysis for the export of agricultural and food industry products ( $\left.y_{2}\right)$ of the Lviv region are presented in Tab. 3. 


\begin{tabular}{|c|c|}
\hline Indicators that reflect the influence of factors & $\left(\mathrm{y}_{1}\right)$ \\
\hline Wholesale turnover, UAH million, food products & 0.984 \\
\hline Share in wholesale turnover, $\%$, food products & 0.754 \\
\hline Share in wholesale turnover, $\%$, non-food products & -0.754 \\
\hline Number of resident population, thousand people & -0.958 \\
\hline Number of resident population by age groups (0-15 years), thousand people & 0.905 \\
\hline Number of resident population by age groups (16-59 years), thousand people & -0.993 \\
\hline Number of resident population by age groups (over 60), thousand people & 0.987 \\
\hline Volume of the minimum wage, UAH & 0.951 \\
\hline Percentage of deductions from wages & 0.956 \\
\hline The unemployed population, on average, thousand people & -0.805 \\
\hline Available income per person, UAH & 0.989 \\
\hline $\begin{array}{l}\text { The structure of total household food expenditures on average per month per household, } \\
\text { UAH }\end{array}$ & 0.986 \\
\hline Final consumer expenditures of households for foodstuffs, UAH million & 0.968 \\
\hline Average monthly expenses per household, UAH & 0.971 \\
\hline Consumption total expenditure on food and non-alcoholic beverages (\%) & -0.832 \\
\hline $\begin{array}{l}\text { Consumption of oil and other vegetable fats in households on average per month per person, } \\
\mathrm{kg}\end{array}$ & -0.951 \\
\hline Consumption of potatoes in households on average per month per person, $\mathrm{kg}$ & -0.828 \\
\hline $\begin{array}{l}\text { Consumption of bread and bread products in households on average per month per person, } \\
\mathrm{kg}\end{array}$ & -0.900 \\
\hline Volumes of the agricultural products exports, USD thousand & 0.832 \\
\hline Volumes of the food industry imports, USD thousand & 0.762 \\
\hline Volume of transported goods by types of transport, thousand tones & 0.798 \\
\hline Expenditures on innovations, UAH million & 0.828 \\
\hline Sown area of agricultural crops, thousand hectares & 0.824 \\
\hline Crop yield, c per 1 ha of harvested area & 0.907 \\
\hline Volume of production (gross yield) of agricultural crops, thousand centners & 0.761 \\
\hline Production of main types of livestock products, thousand tons & -0.979 \\
\hline $\begin{array}{l}\text { Average prices of agricultural products sold by enterprises (cereals and legumes), UAH per } \\
\text { ton }\end{array}$ & 0.952 \\
\hline Average prices of agricultural products sold by enterprises (sunflower), UAH per ton & 0.851 \\
\hline Average prices of agricultural products sold by enterprises (potatoes), UAH per ton & 0.861 \\
\hline Average prices of agricultural products sold enterprises (vegetable crops), UAH per ton & 0.920 \\
\hline Average prices of agricultural products sold by enterprises (farm animals), UAH per ton & 0.990 \\
\hline Average prices of agricultural products sold by enterprises (milk), UAH per ton & 0.982 \\
\hline $\begin{array}{l}\text { Average prices of agricultural products sold by enterprises (eggs, per thousand), UAH per } \\
\text { ton }\end{array}$ & 0.933 \\
\hline Average prices of agricultural products sold by enterprises (all together), UAH per ton & 0.990 \\
\hline Foreign direct investment in agriculture, forestry and fisheries, USD thousand & -0.783 \\
\hline Capital investments in agriculture, hunting and provision of related services, UAH thousand & 0.971 \\
\hline $\begin{array}{l}\text { Capital investments of industrial enterprises (production of food, beverages and tobacco } \\
\text { products), UAH thousand }\end{array}$ & 0.927 \\
\hline GRP of the region, UAH million & 0.995 \\
\hline
\end{tabular}

Tab. 3. The system of correlation between socio-economic factors of the food market and exports of agricultural products and food industry in the Lviv region ( $\left.y_{2}\right)$.

* Source: calculated by the authors 
The first thing to note about the indicator is that exports depend not so much on internal factors as on foreign policy and the global environment, which ultimately showed low values of the correlation coefficients. However, given the number of observation periods, the level of correlation from 0.702 on the Chaddok scale characterizes a strong/moderate influence.

The export of products to foreign markets evidenced by a direct relationship with the indicator of the volume of products sold in the sector under consideration (0.891), the wholesale turnover of both food products (0.901) and non-food products (0.827). The dysfunction can again be noticed by the indirect influence of factors such as the number of resident population by age group $(-0.935)$. This factor, according to the laws of economics, should have a direct impact on the export of agricultural and food industry products ( $\left.\mathrm{y}_{2}\right)$. As in the case of the relationship of socio-economic factors with the volume of products sold (agriculture, food production, beverages) $\mathrm{y}_{1}$, an increase in wages (0.869), final consumer spending (0.821), total expenses on average per month (0.887) increase export volumes of products. However, in this case, this may be evidence of the disadvantage of selling goods on the internal market of products producers or providing an advantage by buyers of imported products. From the data in Table 3 , we can see that the volume of exports increases the volume of imports; therefore, the hypothesis of the priority of imported products with an increase in purchasing power confirmed. From the standpoint of food security in the region, this indicates a lack of confidence in the domestic product quality control system and technical standards.

The costs of innovation have a direct close relationship with the volume of the escort of products, which first testifies to the European integration course of manufacturers and the desire to embody European quality standards.

The expected and positive increase in the volume of exports of agricultural and food products influenced by such factors as the level of development of the crop production sector (crop yield (0.797), sown area of agricultural crops (0.812).

Capital investments in the sector under consideration have a positive effect on the volume of products export (0.819), and the volume of products export affects the increase in the gross regional product of the region (0.815).

The results of the correlation analysis of the influence of factors on the wholesale turnover of food products presented in Tab. 4 .

\begin{tabular}{|l|c|}
\hline \multicolumn{1}{|c|}{ Indicators that reflect the influence of factors } & $\left(\mathrm{y}_{3}\right)$ \\
\hline Volumes of agricultural products and food industry exports, USD thousand & $\mathbf{0 . 9 0 1}$ \\
\hline Volume of sold products (agriculture, production of food, beverages), UAH thousand & $\mathbf{0 . 9 8 4}$ \\
\hline Wholesale turnover, UAH million, non-food products & $\mathbf{0 . 7 2 2}$ \\
\hline Share in wholesale turnover, \%, food products & $\mathbf{0 . 7 4 9}$ \\
\hline Share in wholesale turnover, \%, non-food products & $\mathbf{0 . 7 4 9}$ \\
\hline Number of resident population, thousand people & $\mathbf{0 . 9 2 5}$ \\
\hline Number of resident population by age groups (0-15 years), thousand people & $\mathbf{0 . 9 0 8}$ \\
\hline Number of resident population by age groups (16-59 years), thousand people & $\mathbf{0 . 9 8 2}$ \\
\hline Number of resident population by age groups (over 60), thousand people & $\mathbf{0 . 9 8 3}$ \\
\hline Volume of the minimum wage, UAH & $\mathbf{0 . 9 6 8}$ \\
\hline Percentage of deductions from wages & $\mathbf{0 . 9 7 1}$ \\
\hline The unemployed population, on average, thousand people & $\mathbf{- 0 . 8 4 4}$ \\
\hline Available income per person, UAH & $\mathbf{0 . 9 9 2}$ \\
\hline The structure of total household food expenditures on average per month per household, & \\
UAH & $\mathbf{0 . 9 5 3}$ \\
\hline Final consumer expenditures of households for foodstuffs, UAH million & $\mathbf{0 . 9 2 5}$ \\
\hline Average monthly expenses per household, UAH & $\mathbf{0 . 9 5 6}$ \\
\hline Consumption total expenditure on food and non-alcoholic beverages (\%) & $\mathbf{- 0 . 8 2 9}$ \\
\hline
\end{tabular}




\begin{tabular}{|l|l|}
\hline \multicolumn{1}{|c|}{ Indicators that reflect the influence of factors } & $(\mathbf{y}$ ) \\
\hline $\begin{array}{l}\text { Consumption of oil and other vegetable fats in households on average per month per person, } \\
\mathrm{kg}\end{array}$ & $-\mathbf{0 . 9 0 8}$ \\
\hline Consumption of potatoes in households on average per month per person, $\mathrm{kg}$ & $\mathbf{0 . 7 7 5}$ \\
\hline $\begin{array}{l}\text { Consumption of bread and bread products in households on average per month per person, } \\
\mathrm{kg}\end{array}$ & $\mathbf{- 0 . 8 8 3}$ \\
\hline Volumes of the agricultural products exports, USD thousand & $\mathbf{0 . 8 6 9}$ \\
\hline Volumes of the food industry imports, USD thousand & $\mathbf{0 . 8 0 4}$ \\
\hline Volume of transported goods by types of transport, thousand tones & $\mathbf{0 . 8 3 3}$ \\
\hline Expenditures on innovations, UAH million & $\mathbf{0 . 7 5 7}$ \\
\hline Sown area of agricultural crops, thousand hectares & $\mathbf{0 . 7 3 1}$ \\
\hline Crop yield, c per 1 ha of harvested area & $\mathbf{0 . 8 5 0}$ \\
\hline Production of basic livestock products, thousand tons & $\mathbf{- 0 . 9 4 1}$ \\
\hline $\begin{array}{l}\text { Average prices of agricultural products sold by enterprises (cereals and legumes), UAH per } \\
\text { ton }\end{array}$ & $\mathbf{0 . 9 0 9}$ \\
\hline Average prices of agricultural products sold by enterprises (sunflower), UAH per ton & $\mathbf{0 . 7 9 3}$ \\
\hline Average prices of agricultural products sold by enterprises (potatoes), UAH per ton & $\mathbf{0 . 8 7 7}$ \\
\hline Average prices of agricultural products sold enterprises (vegetable crops), UAH per ton & $\mathbf{0 . 9 6 3}$ \\
\hline Average prices of agricultural products sold by enterprises (farm animals), UAH per ton & $\mathbf{0 . 9 7 5}$ \\
\hline Average prices of agricultural products sold by enterprises (milk), UAH per ton & $\mathbf{0 . 9 6 4}$ \\
\hline $\begin{array}{l}\text { Average prices of agricultural products sold by enterprises (eggs, per thousand), UAH per } \\
\text { ton }\end{array}$ & $\mathbf{0 . 8 8 1}$ \\
\hline Average prices of agricultural products sold by enterprises (all together), UAH per ton & $\mathbf{0 . 9 8 3}$ \\
\hline Capital investments in agriculture, hunting and provision of related services, UAH thousand & $\mathbf{0 . 9 4 8}$ \\
\hline $\begin{array}{l}\text { Capital investments of industrial enterprises (production of food, beverages and tobacco } \\
\text { products), UAH thousand }\end{array}$ & $\mathbf{0 . 9 2 0}$ \\
\hline Volume of sold industrial products (food, beverages and tobacco products), UAH million & $\mathbf{0 . 9 8 4}$ \\
\hline GRP of the region, UAH million & $\mathbf{0 . 9 7 5}$ \\
\hline
\end{tabular}

Tab. 4. The system of interrelation of socio-economic factors and their impact on the wholesale turnover of food products in the Lviv region $\left(y_{3}\right)$

* Source: calculated by the authors

From the presented calculations, we can see that the wholesale turnover of food products "уз" has a positive influence by the following factors:

1) foreign economic activity (export volumes of products (0.901));

2) availability of food products on the market (volumes of sold products of agricultural, food production, beverages (0.984));

3) volume of the population income (volume of the minimum wage (0.968), available income per person (0.992));

4) purchasing power of the population (final consumer expenditures (0.925), total expenditures on average per month (0.956));

5) level of food prices (average prices for all groups of food products have a positive effect on y3);

6) investment climate (capital investments (0.9));

7) innovation activity of enterprises in the analysed sector (expenditures on innovations -0.757 ).

Dysfunctional connections are traced by the following main factors as the number of resident population (-0.925) and by age groups (16-59 years) (-0.982), unemployment (-0.844), as well as consumer spending on food and non-alcoholic beverages (- 0.829). 
The gross domestic product characterizes the final result of the production activity of resident economic units in agriculture (Tab. 5), since the State Statistics Service does not publish data on the food industry.

\begin{tabular}{|c|c|}
\hline Indicators that reflect the influence of factors & $\left(\mathrm{y}_{4}\right)$ \\
\hline Wholesale turnover, UAH million, food products & 0.975 \\
\hline Volumes of agricultural products and food industry exports, USD thousand & 0.815 \\
\hline Volume of sold products (agriculture, production of food, beverages), UAH thousand & 0.995 \\
\hline Share in wholesale turnover, $\%$, food products & 0.741 \\
\hline Share of goods sales produced in Ukraine, food products & 0.742 \\
\hline Number of resident population, thousand people & -0.921 \\
\hline Number of resident population by age groups ( $0-15$ years), thousand people & 0.905 \\
\hline Number of resident population by age groups (16-59 years), thousand people & -0.997 \\
\hline Number of resident population by age groups (over 60), thousand people & 0.995 \\
\hline Volume of the minimum wage, UAH & 0.944 \\
\hline Percentage of deductions from wages & 0.952 \\
\hline Available income per person, $\mathrm{UAH}$ & 0.996 \\
\hline $\begin{array}{l}\text { The structure of total household food expenditures on average per month per household, } \\
\text { UAH }\end{array}$ & 0.992 \\
\hline Final consumer expenditures of households for foodstuffs, UAH million & 0.977 \\
\hline Average monthly expenses per household, UAH & 0.982 \\
\hline Average monthly expenses per household, UAH & -0.802 \\
\hline Consumption total expenditure on food and non-alcoholic beverages (\%) & -0.929 \\
\hline $\begin{array}{l}\text { Consumption of oil and other vegetable fats in households on average per month per } \\
\text { person, } \mathrm{kg}\end{array}$ & -0.883 \\
\hline Consumption of potatoes in households on average per month per person, $\mathrm{kg}$ & -0.926 \\
\hline Crop yield, c per 1 ha of harvested area & 0.904 \\
\hline Production of basic livestock products, thousand tons & -0.967 \\
\hline $\begin{array}{l}\text { Average prices of agricultural products sold by enterprises (cereals and legumes), UAH per } \\
\text { ton }\end{array}$ & 0.974 \\
\hline Average prices of agricultural products sold by enterprises (sunflower), UAH per ton & 0.898 \\
\hline Average prices of agricultural products sold enterprises (vegetable crops), UAH per ton & 0.922 \\
\hline Average prices of agricultural products sold by enterprises (farm animals), UAH per ton & 0.996 \\
\hline Average prices of agricultural products sold by enterprises (milk), UAH per ton & 0.989 \\
\hline $\begin{array}{l}\text { Average prices of agricultural products sold by enterprises (eggs, per thousand), UAH per } \\
\text { ton }\end{array}$ & 0.956 \\
\hline Average prices of agricultural products sold by enterprises (all together), UAH per ton & 0.992 \\
\hline $\begin{array}{l}\text { Capital investments in agriculture, hunting and provision of related services, UAH } \\
\text { thousand }\end{array}$ & 0.978 \\
\hline $\begin{array}{l}\text { Capital investments of industrial enterprises (production of food, beverages and tobacco } \\
\text { products), UAH thousand }\end{array}$ & 0.936 \\
\hline Volume of sold industrial products (food, beverages and tobacco products), UAF & 0.995 \\
\hline
\end{tabular}

Tab. 5. The system of interrelation of socio-economic factors with the resulting "gross regional product" of the Lviv region $\left(y_{4}\right)$.

* Source: calculated by the authors 
The increase in the volume of the gross regional product of the Lviv region has a positive influence by:

1) wholesale trade turnover $(0.975)$, the volume of products export (0.815) and the volume of products sold by agricultural entities, food and beverage production (0.995);

2) increase in income and consumer expenditures of household farms for food (0.996);

3) investment activity of enterprises producing food products (0.978);

4) crop yields and an increase in acreage (0.904);

5) growth in prices for all types of food products (0.991).

Dysfunctional connections can be traced by the following main factors as the number of the resident population (-0.921) and by age groups (16-59 years old) (- 0.997), as well as consumer spending on food and non-alcoholic beverages (- 0.802).

The results of the correlation analysis showed which of the factors of the consumer (food) market have the greatest impact and the indicators that characterize it and, accordingly, the dysfunctions that need for correcting or regulating due to government intervention.

\section{CONCLUSIONS}

Based on the presented analysis, it should be noted that considering the issue of regulators of the regional market development in the aspect of competitive markets, it is worth noting that today in all regions of Ukraine the greatest dysfunctions trace in the consumer goods market. In accordance with this, the main consequences of dysfunctions should be recognized:

1. high level of food exports depends on political factors, imbalance of such a policy in general, the absence of significant exports to the most attractive markets in the world;

2. pronounced disparity in prices for raw materials and final products, which is due to the export of unfinished goods (raw materials), and the import of finished products from domestic raw materials (butter, etc.);

3. technological lag in a number of production capacities for the production of food products, which leads to low productivity and quality of final products;

4. reduction in the production capacity of many types of food products, could not withstand the competition of imported goods;

5. high production costs and, thus, inflated prices on the internal market for domestic products, which leads to the import dependence of a consumer's number on certain groups of goods;

6. transformation of the food sector from a large-scale to a small private sector, which is due to a decrease in demand for domestic goods due to unjustifiably high prices;

7. low investment attractiveness of a number of food production facilities, which leads to obsolescence of fixed assets and inefficiency of production;

8. non-compliance on the market by economic entities with the conditions of state regulation in the pricing policy of some consumer goods, which is due to an ineffective policy of control over the fulfilment of such conditions.

In our opinion, the main directions of the consumer goods market regulation by the authorities are:

- programs to support a number of food producers through financial assistance, providing loans at low interest rates, tax holidays and government support for doing business, in particular business advice;

- state protectionist policy, which will be pursued through the use of such instruments as the provision of subsidies, a decrease in exports or a reduction in imports of manufacturers products in need of protection, which will allow the internal manufacturer to artificially achieve an acceptable level of profitability;

- government intervention in the market environment, providing for a change in the institutional foundations of the existing competitive environment, and thus eliminates economic conflicts between the main groups of market entities. 
It should be noted that today it is impossible to regulate the internal market as a state in general and the region in particular without using regulatory frameworks as the main tool for regulating dysfunctions, and in the regional context, these should be programs for the development of food markets, as the basis for strengthening the food security of the region.

\section{REFERENCES}

[1] Popadynets N.M. Regulation of the internal market development for consumer goods of Ukraine: theory and methodology. Lviv: Dolishniy Institute of Regional Research of NAS of Ukraine, 2020. (in Ukrainian)

[2] Popadynets N.M. Regional consumer goods market: nature and fundamental basics of functioning. Regional economy, 1 (83) (2017), 17-22. Available at: http://re.gov.ua/doi/re2017.01.017_u.php (in Ukrainian)

[3] Popadynets N.M. Structural-institutional model of domestic consumer market. Regional economy, 1 (95) (2020), 137-144. doi: 10.36818/1562-0905-2020-1-13 (in Ukrainian)

[4] Popadynets N.M. Nature of marketing activity in the system of organization of domestic market provision with consumer goods. Regional economy, 4 (94) (2019), 127-136. doi: 10.36818/1562-0905-2019-412 (in Ukrainian)

[5] Lihonenko L.O. (Ed.) Consumer market of Ukraine: research methodology and regulation. Kyiv: KNTEU, 2007. (in Ukrainian)

[6] Yakhno T.P. Development of the national economy in consumer market indicators: theory, methodology, practice: Dr. Sci (Econ.) thesis on specialty 08.00.03. Poltava, 2019. (in Ukrainian)

[7] Drahomyretska M.I. Problems of formation of the consumer market situation in Ukraine. Economics of agro-industrial complex, 10 (2008), 111-118. (in Ukrainian)

[8] Ivashchenko A.V. Problems of economic organization of the consumer market in the transition period. Economy and state, 7 (2008), 34-36. (in Ukrainian)

[9] Azarian O.M. Organizational and economic mechanism of functioning and regulation of the consumer market: author's ref. of the Dr. Sci (Econ.) thesis on specialty 08.02.03. Donetsk, 2003. (in Ukrainian)

[10] Kaplenko H.V. Theoretical and methodological principles of consumer goods market regulation in Ukraine in the context of globalization: Dr. Sci (Econ.) thesis on specialty 08.00.03. Chernihiv, 2020. (in Ukrainian)

Address: Nazariy Popadynets. Scientific-Educational Institute of Entrepreneurship and Perspective Technologies of Lviv Polytechnic National University, 14 Gorbachevsky Str., Lviv, 79044, Ukraine. Viktoriya Bondarenko. Uzhhorod National University, 14 University Str., Uzhhorod, 88000, Ukraine.

Roma Staryk. Lviv State College of Food and Processing Industry of the National University of Food Technologies, 14 I. Pulyuya Str., Lviv, 79060, Ukraine.

Olha Chakii. Uzhhorod National University, 14 University Str., Uzhhorod, 88000, Ukraine.

Olha Voitenko. Dolishniy Institute of Regional Research of NAS of Ukraine, 4 Kozelnytska Str., Lviv, 79034, Ukraine.

E-mail: popadynets.n@gmail.com, viktoriya.bondarenko@gmail.com, romastaryk@ldkhpp.com.ua, olya.chakiy@gmail.com, voytenko1209@gmail.com.

Received: September 11, 2021; revised: October 22, 2021. 
Попадинець Назарій, Бондаренко Вікторія, Старик Рома, Чакій Ольга, Войтенко Ольга. Оцінювання чинників регулювання розвитку ринку споживчих товарів регіону. Журнал Прикарпатського університету імені Василя Стефаника, 8 (3) (2021), 106-119.

На внутрішній ринок споживчих (продовольчих) товарів регіонів України впливає низка економічних, соціально-демографічних, інфраструктурних, екологічних і політичних факторів.

Метою статті є визначення основних дисфункціональних чинників впливу на регулювання розвитку ринку споживчих товарів в регіоні.

Обгрунтовано сутність дисфункцій як ключового явища, яке призводить до деформації чи часткового невиконання функцій суб'єктами внутрішнього споживчого ринку. Досліджено особливості впливу соціально-економічних факторів на ефективність функціонування ринку продовольчих товарів регіону. Здійснено оцінювання впливу чинників ринку продовольчих товарів регіону, шляхом класифікації факторів за сферою впливу та мірою регулювання, оцінювання впливу факторів ринку продовольчих товарів на основні індикаторних моделей, що містять показники, зважаючи на наявну систему статистичного спостереження в регіоні, дослідження зв' язків між факторами та показниками, що характеризують ринок продовольчих товарів і виявлення результатів дисфункцій. Запропоновано блок соціально-економічних детермінантів реалізації потенціалу споживчого (продовольчого) ринку регіону. Здійснено кореляційний аналіз чинників, що впдивають на ринок продоводьчих товарів та обсягу реалізованої продукції (сільське господарство, виробництво харчових продуктів, напоїв). Побудовано систему кореляційного взаємозв'язку соціально-економічних факторів продоводьчого ринку та експорту продукції сільського господарства та харчової промисловості регіону. Запропоновано систему взаємозв'язку соціально-економічних факторів та їх вплив на оптовий товарообіг продовольчих товарів регіону, а також система взаємозв'язку соціально-економічних факторів із результуючим «валовий регіональний продукт». Конкретизовано природу виникнення та сутність дисфункцій регулювання розвитку споживчого ринку. Визначено та охарактеризовано наслідки дисфункцій державного регулювання розвитку внутрішнього ринку споживчих товарів. Згруповано основні дисфункціональні чинники впливу на регулятори розвитку регіонального ринку в аспекті конкурентних ринків.

Кдючові слова: споживчий ринок, продовольчі товари, соціально-економічні фактори, дисфункції, потенціал. 